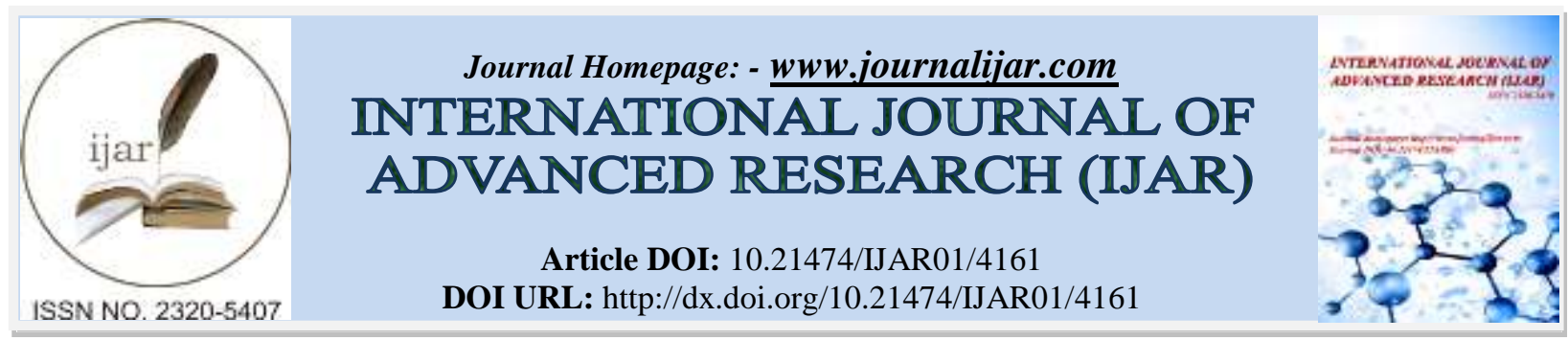

RESEARCH ARTICLE

\title{
EFFECTS OF VERMICOMPOST ON BIOCHEMICAL PARAMETERS OF BENGAL GRAM (CICER ARIETINUM L.) VAR. RSG-896 IN FIELD CONDITIONS.
}

\author{
Preeti Shrimal and T. I. Khan. \\ Indira Gandhi Centre for Human Ecology, Environmental and Population Studies, University of Rajasthan, Jaipur- \\ 302004, India.
}

\section{Manuscript Info}

Manuscript History

Received: 17 March 2017

Final Accepted: 12 April 2017

Published: May 2017

Key words:-

Agricultural fields, Cicer arietinum,

Biochemical parameters,

vermicomposting

\begin{abstract}
Vermicomposting is a system of farming which does not use any form of chemical fertilizers or other agro-chemicals and pesticides. It is dependent entirely on organic sources for crop nutrition and crop husbandry. In this context a field experiment was laid out in a randomized block design (RBD) with three replication in the field located in Bambala, Tehsil- Sanganer, Jaipur. The objective of the experiment was to find out the effects on different combination of vermicompost on the biochemical attributes of Bengal gram (Cicer arietinum L.) var. RSG-896. In field experiment consisted of six treatment levels of vermicompost i.e. $\mathrm{T}_{1}$ which was control level (soil without vermicompost), $\mathrm{T}_{2}, \mathrm{~T}_{3}, \mathrm{~T}_{4}, \mathrm{~T}_{5}$ and $\mathrm{T}_{6}$ of Bengal gram (Cicer arietinum L.) var. RSG-896. In total eighteen plots were maintained. Plants were harvested at three stages i.e. pre-flowering, peak-flowering and post-flowering stages. The results showed an encouraging effect of vermicompost. With the increase in vermicompost level Nitrogen, Protein, Carbohydrate and phosphorus contents increased to 40.21, $40.17,47.39$ and $12.49 \%$ respectively.
\end{abstract}

Copy Right, IJAR, 2017,. All rights reserved.

\section{Introduction:-}

Over a period of several decades it has been observed that agriculture is fully dependent upon chemical fertilizers and chemical pesticides. Due to this large number of environmental and health problems have been introduced. In other hand today every town and city of developed and developing countries are facing the challenges of environmental pollution. More than $65 \%$ of India's urban population living in crowded class and $10 \%$ of it in the over crowed metropolitan cities the situation vis-à-vis solid waste disposal becomes more alarming. As a result our cities and towns are facing the threat of being overrun by garbage and the piled up waste is threatening our health environment and well being. (Sinha et. al., 2002). In this context, the organic manure (vermicompost) is an ecofriendly, economically viable and ecologically sound practice, that played a significant role in soil biology and agriculture. Vermicomposting is bio-oxidation and stabilization of organic material involving the joint action of earthworms and micro-organisms. It also increase $\mathrm{N}_{2}$ fixation by both nodular and free living $\mathrm{N}_{2}$ fixing bacteria and thus enhance plant growth. (Parthasarthi and Ranganathan, 2002). In recent years, vermicomposting has emerged as an efficient technology for recycling wide range of organic waste into good quality compost with the help of epigenic group of earthworms. (Chaudhuri et. al., 2003). Vermicompost is rich in plant nutrients and contains higher number of microorganisms, which are responsible for decomposition process (Yami et. al., 2003). Further, nutrients in vermicompost are often much higher than traditional garden compost (Alam et. al., 2007). Present paper deals 
with the study of the effects of various levels of vermicompost on different parameters like Nitrogen, Protein, Carbohydrate and phosphorus contents of Bengal gram (Cicer arietinum L.) var. RSG-896.

\section{Materials and methods:-}

Experimental setup: For the experimental study Bengal gram (Cicer arietinum L.) var. RSG-896 was selected as test plant. The field experiment was laid out in a randomized block design (RBD) with six treatment levels. The Seeds of Bengal gram (Cicer arietinum L.) var. RSG-896 were obtained from Durgapura Research Experiment Station, Jaipur. Vermicompost was collected from M.R. Morarka-GDC Rural research foundation.

Field (plot) experiments were carried out in the farmer's field located in Bambala, Tehsil- Sanganer, Jaipur, for conducting field experiments for the test plant species Bengal gram (cicer arietinum L.) Var. RSG-896. The total field area divided into six plots. Different level of vermicompost was mixed with soil in the each plot of field area. After mixing of vermicompost with soil ten to fifteen seeds were sown in the beginning in each plot. Three replicates were used for each vermicompost level. In total eighteen plots were maintained. After seedling establishment, a uniform population of five plants for each treatment level and each harvest stage was maintained in each plot of field area up to the termination of the experiment. Thus three plots of field area were maintained for each treatment level.

Six treatment levels of different combinations of soil and vermicompost (VC) were maintained viz. $\mathrm{T}_{1}$ which was control level (soil without vermicompost), $\mathrm{T}_{2}, \mathrm{~T}_{3}, \mathrm{~T}_{4}, \mathrm{~T}_{5}$ and $\mathrm{T}_{6}$ as described below:

$$
\begin{aligned}
& \mathrm{T}_{1}=\quad 0.00 \mathrm{~g} \text { vermicompost }+25,000 \mathrm{gm} \text { soil } \\
& (0.0 \%) \quad(100 \%) \\
& \mathrm{T}_{2}=\quad 312.5 \mathrm{~g} \text { vermicompost }+24,687.5 \mathrm{gm} \text { soil } \\
& (1.25 \%) \quad(98.75 \%) \\
& \mathrm{T}_{3}=625 \mathrm{~g} \text { vermicompost }+24,375 \text { gm soil } \\
& (2.5 \%) \quad(97.50 \%) \\
& \mathrm{T}_{4}=\quad 1250 \mathrm{~g} \text { vermicompost }+23,750 \mathrm{gm} \text { soil } \\
& (5.0 \%) \quad(95.00 \%) \\
& \mathrm{T}_{5}=1875 \mathrm{~g} \text { vermicompost }+23,125 \mathrm{gm} \text { soil } \\
& (7.5 \%) \quad(92.50 \%) \\
& \mathrm{T}_{6}=2500 \mathrm{~g} \text { vermicompost }+22,500 \mathrm{gm} \text { soil } \\
& (10.0 \%) \quad(90.00 \%)
\end{aligned}
$$

Biochemical analysis: Nitrogen and protein content was estimated by microkjeldhal's method. Carbohydrate content was estimated by the Anthrone method and phosphorus content was determined colorimetrically by stannous chloride-ammonium molybdate method.

\section{Result and Discussion:-}

The nitrogen and protein content increased with increasing vermicompost levels as given in the Table I. Figure 1 and 2. Nitrogen was estimate $2.038 \%$ under controlled condition $\left(\mathrm{T}_{1}\right)$ (soil without vermicompost) at the pre flowering stage. It increased up to $2.643 \%$ at the vermicompost level of $\mathrm{T}_{6}$. At the peak flowering stage under controlled condition $\left(\mathrm{T}_{1}\right)$ nitrogen content was $2.206 \%$, which increased up to $2.956 \%$ at the vermicompost level of $\mathrm{T}_{6}$. Similarly nitrogen content was $2.564 \%$ at the post-flowering stage under controlled condition $\left(\mathrm{T}_{1}\right)$ which increased up to $3.595 \%$ at the vermicompost level of $\mathrm{T}_{6}$. Protein content was $12.74 \%$ under controlled condition ( $\mathrm{T}_{1}$ ) (soil without vermicompost) at the pre-flowering stage, which increased up to $16.52 \%$ at the vermicompost level of $\mathrm{T}_{6}$. At the peak-flowering stage under controlled condition $\left(\mathrm{T}_{1}\right)$ protein was estimated $13.79 \%$, which increased up to $18.48 \%$ at the vermicompost level of $\mathrm{T}_{6}$. Similarly protein was estimated $16.03 \%$ at the post-flowering stage under controlled condition $\left(\mathrm{T}_{1}\right)$ which increased up to $22.47 \%$ at the vermicompost level of $\mathrm{T}_{6}$.

The carbohydrate and phosphorus content also increased with increasing levels of vermicomposting as given in the Table II and Figure 3 and 4. Carbohydrate content was $33.31 \mathrm{mg} / \mathrm{gm}$ under controlled condition ( $\mathrm{T}_{1}$ ) (soil without vermicompost) at the pre flowering stage, which increased up to $51.78 \mathrm{mg} / \mathrm{gm}$ at the vermicompost level of $\mathrm{T}_{6}$. At the peak flowering stage under controlled condition $\left(\mathrm{T}_{1}\right)$ carbohydrate content was $41.24 \mathrm{mg} / \mathrm{gm}$ which increased up to $70.43 \mathrm{mg} / \mathrm{gm}$ at the vermicompost level of $\mathrm{T}_{6}$. Similarly carbohydrate content was estimated $42.31 \mathrm{mg} / \mathrm{gm}$ at the 
post flowering stage under controlled conditions $\left(T_{1}\right)$ which increased up to $71.76 \mathrm{mg} / \mathrm{gm}$ at the vermicompost level of $\mathrm{T}_{6}$. Phosphorus content was $3.972 \mathrm{mg} / \mathrm{gm}$ under controlled condition $\left(\mathrm{T}_{1}\right)$ (soil without vermicompost) at the pre flowering stage, which increased up to $4.504 \mathrm{mg} / \mathrm{gm}$ at the vermicompost level of $\mathrm{T}_{6}$. At the peak flowering stage under controlled condition $\left(\mathrm{T}_{1}\right)$ phosphorus content was $4.064 \mathrm{mg} / \mathrm{gm}$ which increased up to $4.532 \mathrm{mg} / \mathrm{gm}$ at the vermicompost level of $\mathrm{T}_{6}$. Similarly phosphorus content was estimated $4.114 \mathrm{mg} / \mathrm{gm}$ at the post flowering stage under controlled conditions $\left(\mathrm{T}_{1}\right)$ which increased up to $4.628 \mathrm{mg} / \mathrm{gm}$ at the vermicompost level of $\mathrm{T}_{6}$.

The analysis of variance (ANOVA) revealed that with the increase in vermicompost levels, there was increase in all the parameters of Bengal gram (Cicer arietinum L.) var. RSG-896. The results are highly significant for harvesting stages, the different vermicompost levels and interactions among the harvesting stages and the vermicompost level maintained in the experiment.

Table I: - Effects of vermicompost on Nitrogen and Protein content of Bengal gram (Cicer arietinum L.) var. RSG896 through field experiment.

\begin{tabular}{|c|c|c|c|c|c|c|c|}
\hline S.No. & Treatment & \multicolumn{2}{|c|}{ Pre- flowering } & \multicolumn{2}{c|}{ Peak-flowering } & \multicolumn{2}{c|}{ Post-flowering } \\
\cline { 3 - 8 } & level & \% Nitrogen & \% Protein & \% Nitrogen & \% Protein & \% Nitrogen & $\%$ Protein \\
\hline 1 & $\mathrm{~T}_{1}$ & $2.038 \pm 0.050$ & $12.74 \pm 0.313$ & $2.206 \pm 0.050$ & $13.79 \pm 0.313$ & $2.564 \pm 0.046$ & $16.03 \pm 0.292$ \\
\hline 2 & $\mathrm{~T}_{2}$ & $2.161 \pm 0.050$ & $13.51 \pm 0.313$ & $2.385 \pm 0.084$ & $14.91 \pm 0.530$ & $2.800 \pm 0.068$ & $\begin{array}{c}17.50 \pm 0.428 \\
(9.17)\end{array}$ \\
\hline 3 & & $(6.03)$ & $(6.04)$ & $(8.11)$ & $(8.12)$ & $(9.20)$ & $(12)$ \\
& $\mathrm{T}_{3}$ & $2.284 \pm 0.061$ & $14.28 \pm 0.383$ & $2.531 \pm 0.092$ & $15.82 \pm 0.575$ & $3.057 \pm 0.116$ & $\begin{array}{c}19.11 \pm 0.725 \\
(19.21)\end{array}$ \\
\hline 4 & & $(12.07)$ & $(12.08)$ & $(14.73)$ & $(14.72)$ & $(19.22)$ & $(12)$ \\
& $\mathrm{T}_{4}$ & $2.408 \pm 0.039$ & $15.05 \pm 0.247$ & $2.676 \pm 0.073$ & $16.73 \pm 0.456$ & $3.236 \pm 0.061$ & $\begin{array}{c}20.23 \pm 0.383 \\
(16.20)\end{array}$ \\
\hline 5 & & $(18.15)$ & $(18.13)$ & $(21.30)$ & $(21.31)$ & $(26.20)$ & $(26)$ \\
& $\mathrm{T}_{5}$ & $2.520 \pm 0.056$ & $15.75 \pm 0.350$ & $2.856 \pm 0.068$ & $17.85 \pm 0.428$ & $3.460 \pm 0.046$ & $21.63 \pm 0.292$ \\
& & $(23.65)$ & $(23.62)$ & $(29.46)$ & $(29.44)$ & $(34.94)$ & $(34.93)$ \\
\hline 6 & $\mathrm{~T}_{6}$ & $2.643 \pm 0.046$ & $16.52 \pm 0.292$ & $2.956 \pm 0.083$ & $18.48 \pm 0.519$ & $3.595 \pm 0.092$ & $22.47 \pm 0.575$ \\
& & $(29.68)$ & $(29.67)$ & $(33.96)$ & $(34.01)$ & $(40.21)$ & $(40.17)$ \\
\hline
\end{tabular}

* Mean of five replicates \pm standard deviation; Data in parenthesis denotes percentage increase

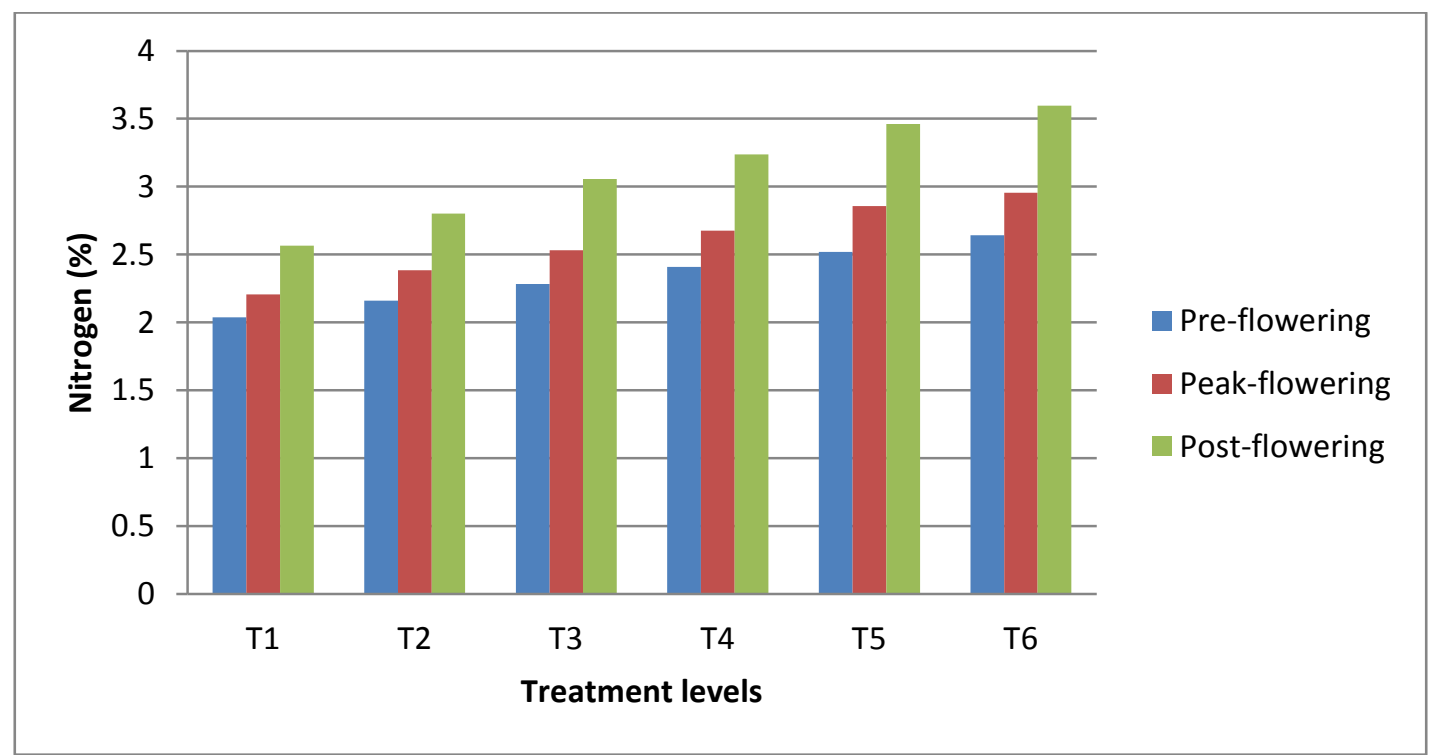

Figure 1:-Effects of different levels of vermicompost on Nitrogen content of Bengal gram (Cicer arietinum L.) var. RSG-896 in the field experiment. 


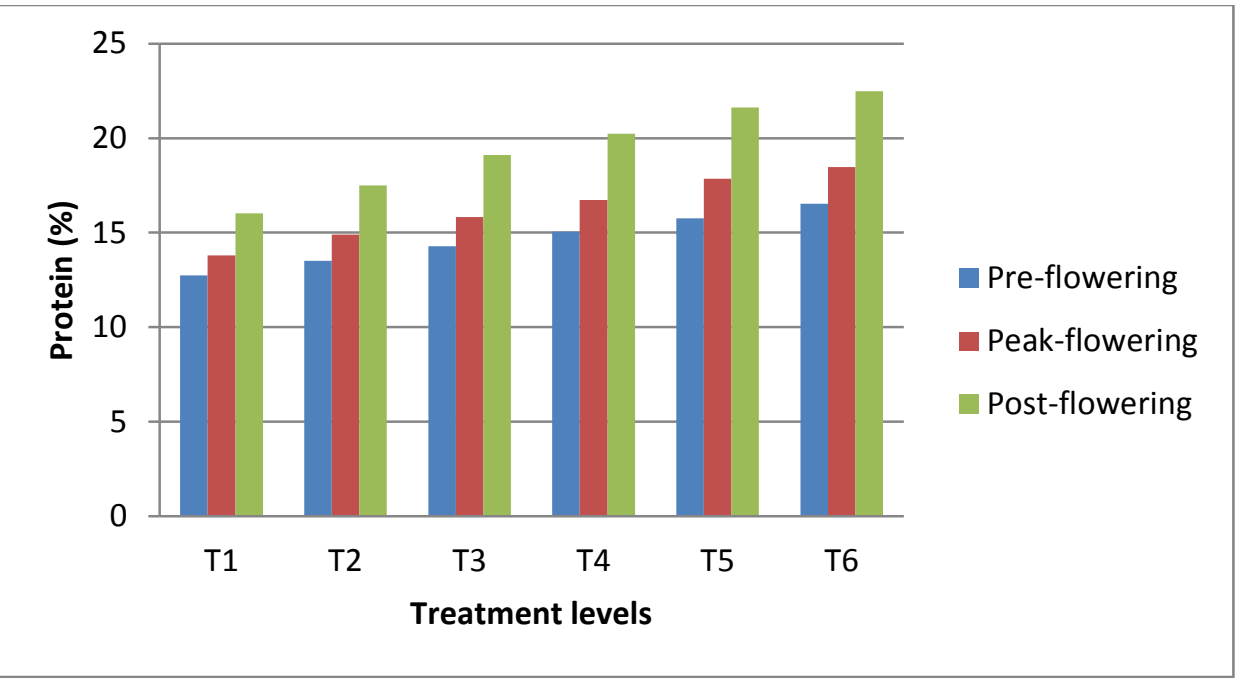

Figure 2:- Effects of different levels of vermicompost on Protein content of Bengal gram (Cicer arietinum L.) var. RSG-896 in the field experiment.

Table II: - Effects of vermicompost on Carbohydrate and Phosphorus content of Bengal gram (Cicer arietinum L.) var. RSG-896 through field experiment.

\begin{tabular}{|c|c|c|c|c|c|c|c|}
\hline \multirow[t]{2}{*}{ S.No. } & \multirow{2}{*}{$\begin{array}{c}\text { Treatment } \\
\text { level }\end{array}$} & \multicolumn{3}{|c|}{ Carbohydrate (mg/gm) } & \multicolumn{3}{|c|}{ Phosphorus (mg/gm) } \\
\hline & & $\begin{array}{c}\text { Pre- } \\
\text { flowering }\end{array}$ & $\begin{array}{c}\text { Peak- } \\
\text { flowering }\end{array}$ & $\begin{array}{c}\text { Post- } \\
\text { flowering }\end{array}$ & $\begin{array}{c}\text { Pre- } \\
\text { flowering }\end{array}$ & $\begin{array}{c}\text { Peak- } \\
\text { flowering }\end{array}$ & Post-flowering \\
\hline 1 & $\mathrm{~T}_{1}$ & $33.31 \pm 0.157$ & $41.09 \pm 0.227$ & $42.31 \pm 0.070$ & $3.972 \pm 0.061$ & $4.064 \pm 0.036$ & $4.114 \pm 0.043$ \\
\hline 2 & $\mathrm{~T}_{2}$ & $\begin{array}{c}37.57 \pm 0.162 \\
(9.14)\end{array}$ & $\begin{array}{c}50.21 \pm 0.066 \\
(14.89)\end{array}$ & $\begin{array}{c}51.32 \pm 0.163 \\
(14.49)\end{array}$ & $\begin{array}{c}4.054 \pm 0.033 \\
(2.06)\end{array}$ & $\begin{array}{c}4.132 \pm 0.043 \\
(1.67)\end{array}$ & $\begin{array}{c}4.158 \pm 0.019 \\
(1.06)\end{array}$ \\
\hline 3 & $\mathrm{~T}_{3}$ & $\begin{array}{c}39.78 \pm 0.328 \\
(13.89)\end{array}$ & $\begin{array}{c}56.25 \pm 0.106 \\
(24.75)\end{array}$ & $\begin{array}{c}57.34 \pm 0.102 \\
(24.18)\end{array}$ & $\begin{array}{c}4.094 \pm 0.024 \\
(3.07)\end{array}$ & $\begin{array}{c}4.184 \pm 0.077 \\
(2.95)\end{array}$ & $\begin{array}{c}4.212 \pm 0.086 \\
(2.38)\end{array}$ \\
\hline 4 & $\mathrm{~T}_{4}$ & $\begin{array}{c}43.90 \pm 0.338 \\
(22.74)\end{array}$ & $\begin{array}{c}60.83 \pm 0.372 \\
(32.23)\end{array}$ & $\begin{array}{c}61.48 \pm 0.346 \\
(30.84)\end{array}$ & $\begin{array}{c}4.15 \pm 0.025 \\
(4.48)\end{array}$ & $\begin{array}{c}4.306 \pm 0.098 \\
(5.95)\end{array}$ & $\begin{array}{c}4.464 \pm 0.113 \\
(8.50)\end{array}$ \\
\hline 5 & $\mathrm{~T}_{5}$ & $\begin{array}{c}47.52 \pm 0.128 \\
(30.51)\end{array}$ & $\begin{array}{c}65.21 \pm 0.153 \\
(39.38)\end{array}$ & $\begin{array}{c}66.42 \pm 0.273 \\
(38.79)\end{array}$ & $\begin{array}{c}4.28 \pm 0.029 \\
(7.75)\end{array}$ & $\begin{array}{c}4.41 \pm 0.067 \\
(8.51)\end{array}$ & $\begin{array}{c}4.574 \pm 0.071 \\
(11.18)\end{array}$ \\
\hline 6 & $\mathrm{~T}_{6}$ & $\begin{array}{c}51.78 \pm 0.126 \\
(39.66)\end{array}$ & $\begin{array}{c}70.43 \pm 0.108 \\
(47.90)\end{array}$ & $\begin{array}{c}71.76 \pm 0.082 \\
(47.39)\end{array}$ & $\begin{array}{c}4.504 \pm 0.080 \\
(13.39)\end{array}$ & $\begin{array}{c}4.532 \pm 0.093 \\
(11.51)\end{array}$ & $\begin{array}{c}4.628 \pm 0.087 \\
(12.49)\end{array}$ \\
\hline
\end{tabular}

* Mean of five replicates \pm standard deviation; Data in parenthesis denotes percentage increase

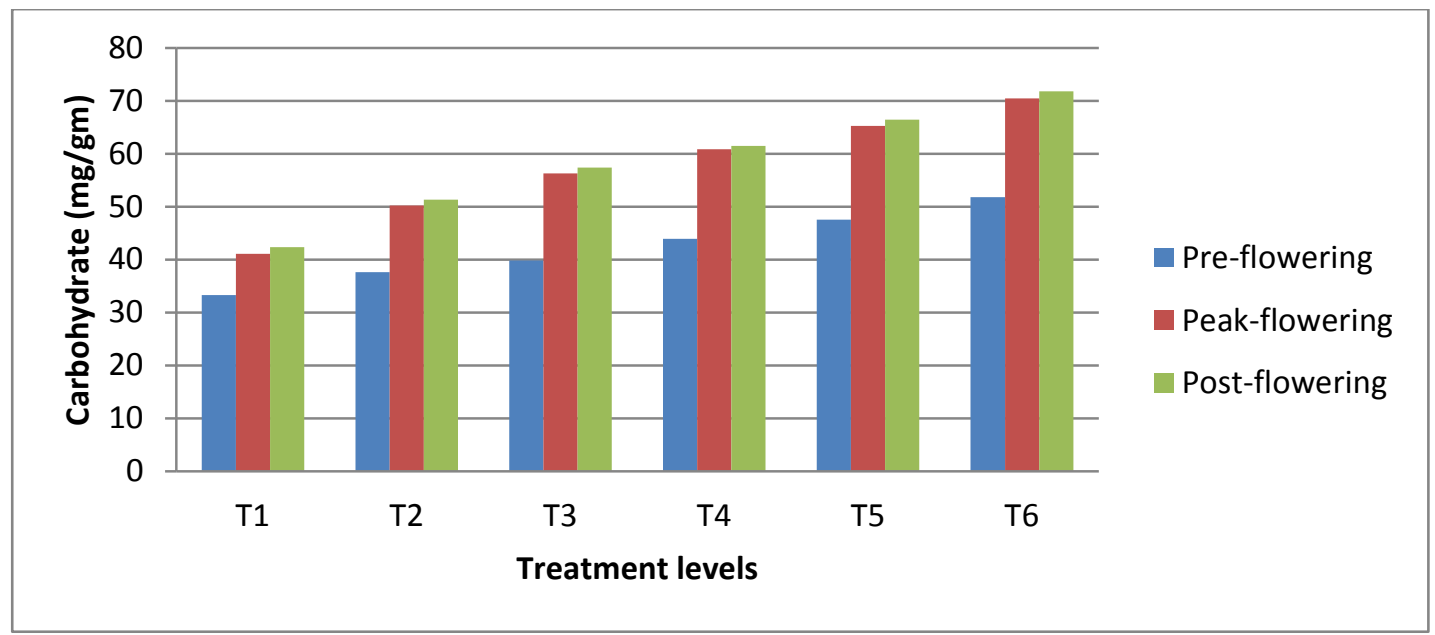

Figure 3:- Effects of different levels of vermicompost on Carbohydrate content of Bengal gram (Cicer arietinum L.) var. RSG-896 in the field experiment. 


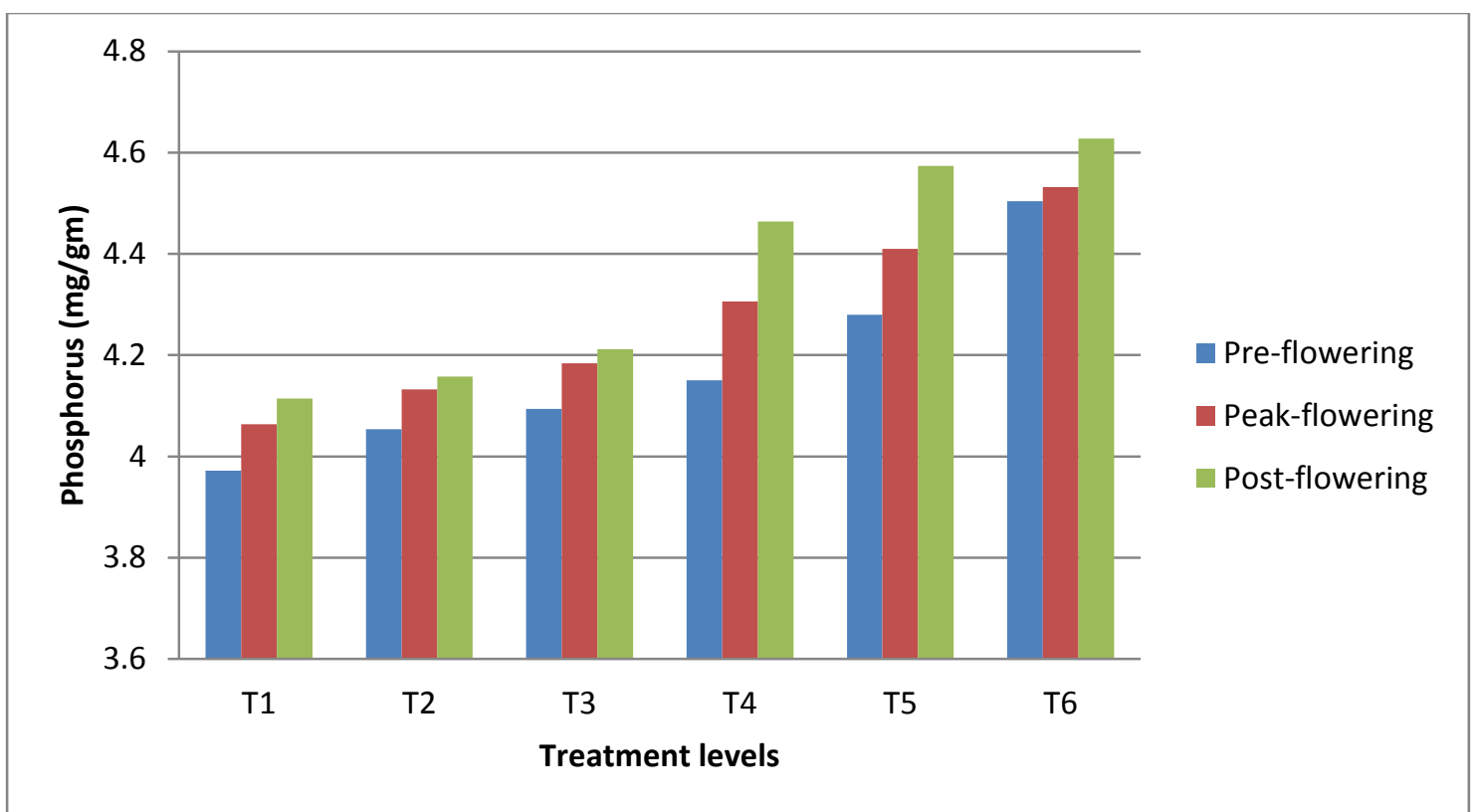

Figure 4:- Effects of different levels of vermicompost on Phosphorus content of Bengal gram (Cicer arietinum L.) var. RSG-896 in the field experiment.

Table III: - Mean sum of squares due to effects of vermicompost on different parameters of Bengal gram (Cicer arietinum L.) var. RSG-896 through field experiment.

\begin{tabular}{|l|l|l|l|l|l|}
\hline Source & DF & Nitrogen & Protein & Carbohydrate & Phosphorus \\
\hline Replicates & 4 & 0.002 & & & \\
& & $(0.840982)$ & 0.085 & 0.057 & 0.006 \\
Stage & 2 & 4.688 & 183.142 & $(0.2693)$ & $(0.218813)$ \\
\hline Treatment & & $\left(2.01 \mathrm{E}-50^{* *}\right)$ & $\left(1.7 \mathrm{E}-50^{* *}\right)$ & $\left(3.5 \mathrm{E}-110^{* *}\right)$ & $\left(2.65 \mathrm{E}-15^{* *}\right)$ \\
& 5 & 1.356 & 52.953 & 1297.502 & 0.568 \\
& & $\left(1.17 \mathrm{E}-43^{* *}\right)$ & $\left(9.9 \mathrm{E}-44^{* *}\right)$ & $\left(3.2 \mathrm{E}-112^{* *}\right)$ & $\left(2.29 \mathrm{E}-33^{* *}\right)$ \\
\hline Interaction & 10 & 0.037 & 1.438 & 27.908 & 0.012 \\
(StagexTreatment) & & $\left(7.11 \mathrm{E}-08^{* *}\right)$ & $\left(6.54 \mathrm{E}-08^{* *}\right)$ & $\left(2.93 \mathrm{E}-63^{* *}\right)$ & $\left(0.005253^{* *}\right)$ \\
\hline Error & 68 & 0.005 & 0.192 & 0.043 & 0.004 \\
\hline
\end{tabular}

Data in parenthesis indicate $\mathrm{P}$ values.

$\mathrm{P}<.01$ e.i. Highly significant

$\mathrm{P}<.05$ e.i. significant at $5 \%$ only

The results are non significant for replicates. Mean sum of square (MSS) and P values are given in the Table III.

The present study shows that application of vermicompost enhanced the growth percentage in Bengal gram (Cicer arietinum L.) var. RSG-896. This confirms the earlier observations (Arancon et.al; 2003; Edward et.al; 2004; Alam et.al; 2007; Ansari, 2008a and Ansari, 2008b). Vermicompost enhanced plant production, mineral nutrients and total carotenoids, and this effect was most prominent under organic fertilization. (Pant et.al; 2009). Application of vermicompost was reported by (Chamani et.al;2008; Suthar, 2009 Sinha et.al; 2010; Tharmaraj et.al; 2011 and Chanda et.al;2011) and reported that the vermicompost treated plants exhibit faster and higher growth rate and productivity than the control plants.

\section{Conclusion:-}

Vermicompost beneficially affect soil structure and nutrient availability, maintain quantity and quality of yield, and can be less costly than synthetic fertilizers. The use of vermicompost can increase fertility without negative effects on human health and environment. We counsel farmers to use vermicompost in organic cultivation of Bengal gram (Cicer arietinum L.) var. RSG-896. Use of vermicompost in field provides better crop growth and yield of Bengal 
gram (Cicer arietinum L.) var. RSG-896. Even at the lower dose than that of the recommended dose of the vermicompost has shown better results for nodulation and crop yield, which is not only economical but also beneficial with soil improvement point of view. Results revealed that in treatment level 6 i.e. $\mathrm{T}_{6}$ plant growth response remained the best. In this treatment level, highest level of vermicompost was applied. It is therefore most necessary to reduce the dependence on chemical inputs in agriculture. At last there is an urgent need to transfer this technology on the farmer's field on large scale. This is possible only through ecofriendly approaches of farming system.

\section{References:-}

1. Alam, M.N., Jahan, M.S., Ali, M.K., Ashraf M.A. and Islam M.K. (2007): Effect of vermicompost and chemical fertilizers on growth, yield and yield components of Potato in Barind soils of Bangladesh. J. Appl. Sci. Res., 3(12): 1879-1888.

2. Ansari, A.A. (2008a): Effect of vermicompost and vermiwash on the productivity of Spinach (Spinacia oleracea), Onion (Allium cepa) and Potato (Solanum tuberosum). World J. Agricul. Sci., 4(3):554-557.

3. Ansari, A.A. (2008b): Effect of vermicompost on the productivity of Potato (Solanum tuberosum), Spinach (Spinacia oleracea) and Turnip (Brassica campestris). World J. Agricul. Sci., 4(3):333-336.

4. Arancon, N.Q., Edwards, C.A., Bierman, P., Metzger, J.D., Lee, S. and Welch, C. (2003): Effects of vermicomposts on growth and marketable fruits of field-grown Tomatoes, Peppers and Strawberries. Pedobiologia., 47:731-735.

5. Chamani, E., Joyce, D.C. and Reihanytabar, A. (2008): Vermicompost effects on the growth and flowering of Petunia hybrida 'Dream Neon Rose'. American-Eurasian J. Agric. and Environ. Sci,. 3(3):506-512.

6. Chanda, G.K., Bhunia, G. and Chakraborty, S. K. (2011): The effect of vermicompost and other fertilizers on cultivation of tomato plants. J. Horticul. and Forestry., 3(2):42-45.

7. Chaudhuri, P.S., Pal, T.K., Bhattacharjee, G. and Dey, S.K. (2003): Rubber leaf litters (Hevea brasiliensis, ver RRI M 600) as Vermiculture substrate for epizeic earthworms, Perionyx excavatus, Endrilus eugeniae and Eisenia foetida. Pedobiologia, 47: 796-800.

8. Edwards, C.A., Dominguez, J. and Arancon, N. Q. (2004): The influence of vermicomposts on plant growth and pest incidence. Soil zoology for Sustainable Development in the 21th Century.

9. Pant, A.P., Radovich, T.J.K, Hue, N.V., Talcott, S.T. and Krenek, K.A. (2009): Vermicompost extracts influence growth, mineral nutrients, phytonutrients and antioxidant activity in Pak choi (Brassica rapa cv. Bonsai, Chinensis group) grown under vermicompost and chemical fertilizer. J Sci Food Agric., Society of Chemical Industry.

10. Parthasarthi, K. and Ranganathan, L.S. (2002): Supplementation of presumed vermicast with NPK enhances growth and yield in Leguminous crop (Vigna mungo and Arachis hypogaea). J. Curr. Sci., 2(1):35-41.

11. Sinha, J., Biswas, C.K., Ghosh, A. and Saha, A. (2010): Efficacy of vermicompost against fertilizers on Cicer and Pisum and on population diversity of $\mathrm{N}_{2}$ fixing bacteria. J. Environ. Biol., 31:287-292.

12. Sinha, M.P., Srivastava, R., Kumar, M. and Choudhary, A.K. (2002): Vermiculture Biotechnology for pollution control. Journal of Environment and pollution technology, 1(4):401-405.

13. Suthar, S. (2009): Impact of vermicompost and composted farmyard manure on growth and yield of garlic (Allium stivum L.) field crop. Inter. J. Plant Production, 3(1):27-38.

14. Tharmaraj, k., Ganesh, P., Kolanjinathan, K. Kumar, R.S. and Anandan, A.(2011): Influence of vermicompost and vermiwash on physico chemical properties of rice cultivated soil. Curr. Bot., 2(3):18-21.

15. Yami K.D., Bhattarai, S. and Adhikari, S. (2003): Vermicomposting and microflora analysis of vermicompost and gut of red earthworm. Nepal Journal of Science and Technology, 5:127-132. 